\title{
Biomobilization of heavy metals from the sediments affect the bacterial population of Al-Ghadir River (Lebanon)
}

\author{
Amale Mcheik $^{1,2, *}$, Mohamad Fakih ${ }^{1,2}$, Noureddine Bousserrhine ${ }^{1}$, Joumana Toufaily ${ }^{2,3}$, \\ Evelyne Garnier-Zarli ${ }^{1}$, Taysir Hamieh $^{2}$ \\ ${ }^{1}$ Paris-Est University, Créteil, France \\ ${ }^{2}$ Lebanese University, Hadath, Beirut, Lebanon \\ ${ }^{3}$ School of Mechanical and Materials Engineering, Washington State University, Pullman, WA 99164, United States of America
}

\section{Email address:}

Amale.am@hotmail.com(A. Mcheik), fakih.mohamad@gmail.com(M. Fakih), bousserrhine@u-pec.fr(N. Bousserrhine), joumana.toufaily@ul.edu.lb(J. Toufaily),garnier@u-pec.fr(E. Garnier-Zarli), tayssir.hamieh@ul.edu.lb(H. Taysir)

\section{To cite this article:}

Amale Mcheik, Mohamad Fakih, Noureddine Bousserrhine, Joumana Toufaily, Evelyne Garnier-Zarli, Taysir Hamieh. Biomobilization of Heavy Metals from the Sediments Affect the Bacterial Population of Al-Ghadir River (Lebanon). Agriculture, Forestry and Fisheries. Vol. 2, No. 3, 2013; pp. 116-125.doi: 10.11648/j.aff.20130203.11

\begin{abstract}
Although there is no doubt about the importance of the bacterial activity on the solubilisation and the distribution of heavy metals in aquatic sediments, hydromorphic soils and ground waters; little is known about the involvement of bacterial dissolution in periodically anaerobic environments like that found in dredged sediments and little is known about the processes and the environmental factors controlling this process. The aim of this paper was to study the effect of the autochthonous bacterial activity on the biodegradation of organic matter and the mobilization of heavy metals in the sediments of Al-Ghadir river (Mount Lebanon). Sediments were incubated under standard anaerobic conditions and enriched with glucose to stimulate and accelerate microbial metabolism. The evolution of carbon metabolism (Organic matter evolved, carbon consumed and organic acids produced) and metals released in batch reactors were followed over time. Under the adopted conditions, analysis of the chemical parameters indicated that the incubated sediments showed a significant release of organic carbon corresponding to bacterial development. Mineral analysis showed an important solubilisation of $\mathrm{Fe}^{2+}$ and $\mathrm{Mn}^{2+}$ indicating the presence of $\mathrm{Fe}$ - and Mn-reducing bacteria in sediments. $\mathrm{Pb}, \mathrm{Cd}$ and $\mathrm{Cr}$ solubilisation profiles were observed and appeared concomitant to the solubilisation profiles of Fe and $\mathrm{Mn}$ indicating that the redox cycle has been well installed and that $\mathrm{Pb}, \mathrm{Cd}$ and $\mathrm{Cr}$ were associated to $\mathrm{Fe}$ and $\mathrm{Mn}$ oxides. The production of $\mathrm{Cu}$ appeared in parallel to the mineralization of the organic matter in the sediment indicating that $\mathrm{Cu}$ was associated to this fraction. $\mathrm{Zn}$ appeared associated to the sulphide fraction than to the Fe and Mn oxides fraction. Microbiological and genetic analysis showed a decrease and the disappearance of some bacterial strains due to the shift in the culture conditions and the toxicity of the released heavy metals but at the same time the development and the growth of many other populations which showed to be tolerant to the same conditions.
\end{abstract}

Keywords: Mobilization of Heavy Metals, Incubated River Sediments, Fe- and Mn-Reducing Bacteria

\section{Introduction}

The biogeochemical cycle of heavy metals has been greatly accelerated by human activities. Heavy metals enter the ecosystem through both natural and anthropogenic processes. Some soils have been found to have a high background of some trace elements which are toxic to plants and wildlife.

Anthropogenic processes include inputs of heavy metals from industrial and municipal effluents, land-fill leaching, non-point source run-off, and atmospheric deposition $[1,2]$.
When these metals discharge to the aquatic environment, the metal is partitioned between the sediment and the water column phases. Further partitioning of metals occurs within the sediment chemical fractions and metal speciation occurs in water column with different ligands $[3,4]$. This process of metal speciation may lead to the self-purification of rivers from metal pollution.

Accumulation of these heavy metals in different compartments of the environment, and particularly in the river sediments, and their possible mobilization under environmentally changing conditions induce a perturbation 
of both the structure and the function of the ecosystem and might cause adverse health effect to biota [5].

Only a small portion of heavy metals in soil is bioavailable. The mobility and availability of these pollutants are controlled by many physico-chemical conditions such as the acidification of the medium or a change in the redox conditions [6, 7, 8, 9]. If the physico-chemical parameters can roughly explain the overall solubilization patterns of heavy metals and their repartition in the different fractions of sediments, the autochthonous microbial activities play a major role on the fate of metals in the aquatic systems, in soils and in sediments $[10,11,12,13,14]$. They can provoke a severe acidification of the medium during sulfide oxidation $[15,16$, 17] or reduce iron oxide [18]. Conversely, other organisms can also promote the oxidation of $\mathrm{Fe}$ oxides. If such phenomena have been described in soils, studies in sediments are very seldom and particularly in strictly anaerobic conditions $[19,20]$. However, it is necessary to understand the microbial activity in anoxic sediments since the potential release of metals, particularly in fresh water, may contaminate the neighboring ground water masses, for example, in the case of storage of dredged sediments in wet ponds [21, 22].

In addition to the role of the autochtonous microbes on the solubilisation of heavy metals, few studies have been served to highlight the subtle effects of heavy metal pollution on the structure of the soil microbial communities or on the genetic diversity of particular groups of organisms. Evidence from the field experiments suggests that under long-term metal stress, a change in the genetic structure of the soil microbial community will be produced [6]. A decrease in the total soil microbial biomass under chronic metal stress has been observed in many field experiments, but is likely to be preceded by changes in community structure. A decrease in the size of the microbial biomass could at least partially be explained by physiological causes such as a decrease in the microbial substrate utilization efficiency, depletion of oxygen and an increased maintenance energy required which varies in the order: fungi $>$ bacteria $>$ actinomycetes. Genetic diversity is always present within species and may be crucial in determining the response of a population to changing conditions $[12,13,14]$. A decrease in the number of substrates which can be utilized and thus a reduction in the efficient exploitation of all ecological niches may also explain the decrease in the size of the biomass.

In the present paper, an attempt has been made to study the impact of the autochthonous bacterial activity on the biodegradation of organic matters and mobilization of heavy metals contained in the sediments of the river. Sediments were sampled and incubated in anaerobic conditions (batch cultures) and the release of metals and their distribution patterns as well as microbial metabolism were monitored during the incubation period.

\section{Materials and Methods}

\subsection{Study Area}

Despite the small size of the river Al-Ghadir $(15 \mathrm{~km}$ length, width $<3 \mathrm{~m}$ ) it is considered one of the most polluted rivers in Lebanon and it is the primary source of pollution of the Mediterranean Sea.

Different sources of pollution have been identified for this river: (1) Releases of solid and liquid wastes containing heavy metals and organic pollutants from different plants (especially in the lower course of the river). (2) Direct discharge of sewages and household wastes especially in the upper course where the river runs through crowded residential neighborhood. All these sources have meant that the water and the sediments of this river have significant levels of organic matter and heavy metals.

\subsection{Sampling Methodology}

Bed load sediments and water were collected from a site of Al-Ghadir River in November 2010 (Fig.1).

This site is located at the end of the river just before its water passes in tunnels near the airport and before its release to the Mediterranean Sea. This study focused on this site (site E) which was shown to be the most polluted site chemically and microbiologically as the water of the river passes downstream carrying with it most of the pollutants.

The collection of bed load sediments was in accordance with the methods used for shallow rivers [23, 24]. The method involves wading in water and scooping sediments from the first twenty centimeters using an aluminium trowel. Once collected, sediment samples were transferred into $10 \mathrm{~L}$ plastic bottle previously washed with $10 \%(\mathrm{v} / \mathrm{v})$ nitric acid to avoid any metallic contamination.

Water samples were collected using 2 one-liter polyethylene bottles that have been soaked overnight in $10 \%(\mathrm{v} / \mathrm{v})$ nitric acid. The bottles were rinsed twice with the river water and then filled with water running in the direction of the river flow and acidified (with $2 \%$ nitric acid) for heavy metal analysis.

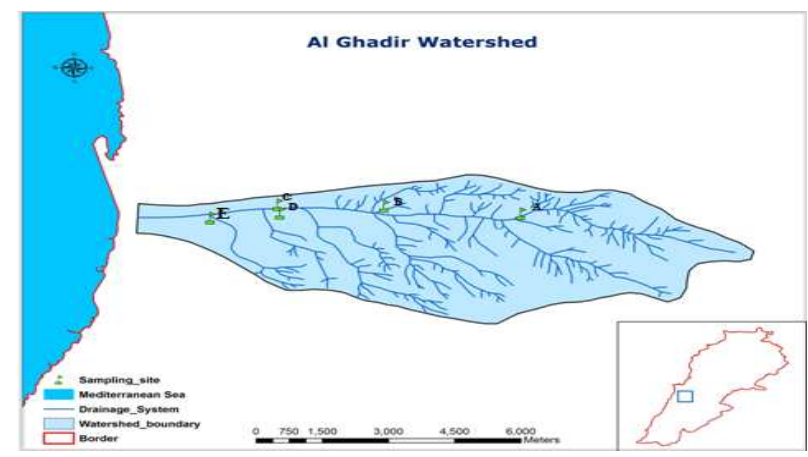

Figure 1. A map of the study area showing the sampling site

Water samples were collected using 2 one-liter polyethylene bottles that have been soaked overnight in $10 \%(\mathrm{v} / \mathrm{v})$ nitric acid. The bottles were rinsed twice with the river water and then filled with water running in the 
direction of the river flow and acidified (with $2 \%$ nitric acid) for heavy metal analysis.

\subsection{Experimental Design}

Sediment incubations were carried out in anaerobic conditions in soil microcosms. These microcosms were carried out in closed autoclaved glass vials of $45 \mathrm{ml}$ containing $3 \mathrm{~g}$ of soil and $30 \mathrm{ml}$ of Bromfield medium amended by Bousserrhine $[25,26]$ and sterilized by autoclaving. The incubation started when $3 \mathrm{~g}$ (dry weight) were added to $30 \mathrm{ml}$ sterilized culture medium containing 10 g.l-1 of glucose (C source) and 0.15 g.l-1 of yeast extract ( $\mathrm{N}$ source). This culture medium was used to stimulate bacterial growth, accelerate the evolution of sediments and study the impact of microbial activity on the release of metals. The anaerobic conditions were created by degassing the system with nitrogen. Incubations were conducted in the dark at $28 \pm 2^{\circ} \mathrm{C}$ for 10 days without shaking to avoid resuspension of sediments and consequently to only consider diffusion of metals during the incubation and simulate diffusion of metals in calm and anaerobic areas. Incubations of sediments were realized in triplicates and all manipulations were done under a sterilized hood to avoid any microbial contamination.

\subsection{Study of the Microbial Metabolism, Density and Diversity}

\subsubsection{Study of the Microbial Metabolism}

$\mathrm{Ph}$ was measured in the culture medium sampled with a sterile syringe through the septum to keep anaerobic conditions and filtered through a $0.45 \mu \mathrm{m}$ (pore diameter) cellulose acetate filter. Glucose was measured enzymatically in $1 \mathrm{ml}$ of the culture medium using a commercial kit (kit D-Glucose/, Roche). Total organic carbon (TOC) and organic carbon (OC) were measured by an elemental analyser (Bruker, D8, France). Butyrate, acetate, succinate and lactate which are the main organic acids produced during glucose fermentation [18] were analysed in $1 \mathrm{ml}$ of medium solution by HPLC according to Tormo and Izco [27]. Separation of organic acids was realized by HPLC with a reversed phase column (Thermo ODS hypersil $5 \mu \mathrm{m}, 4.6^{*} 250 \mathrm{~mm}$ ) and a gradient of $\mathrm{KH} 2 \mathrm{PO} 4(20 \mathrm{mM})$ and acetonitrile.

\subsubsection{Study of the Microbial Density}

Aerophiles, enterococcus, total coliforms (TC) and fecal coliforms (FC), iron reducing bacteria and Clostridium perfringes were detected and enumerated in the sediment samples before and after incubation. Sediment samples were serially diluted and spreaded over the surface of MacConkey agar plates, slanetz, Count Agar Plates (PCA), Tryptone Sulfite Neomycin Agar (TSN) and Bromfield solid media plates modified by Bousserrhine [28] for the detection of TC and FC, enterococcus, aerophiles, Clotridium perfringes and iron -reducing bacteria, respectively. The inoculated plates were then either incubated aerobically for $24 \mathrm{hrs}$ at $37^{\circ} \mathrm{C}$ for the detection of $\mathrm{TC}$, aerophiles and enterococcus and $44^{\circ} \mathrm{C}$ for the detection of fecal coliforms and Clostridium perfringes or anaerobically at $28^{\circ} \mathrm{C}$ for the detection of the iron-reducing bacteria and the number of colonies were counted and recorded as the colony forming units (CFU) per gram soil of dry weight.

\subsubsection{Study of the Microbial Diversity}

Total DNA was extracted from $0.25 \mathrm{~g}$ of sediments taken from the sediment samples before and during their incubation using DNA extraction kits (PowersoilTM, MO BIO Laboratories, Ozyme, France). After extraction, DNA was quantified by UV spectrophometry at $260 \mathrm{~nm}$ (ND-1000 Spectrophotometer, Nanodrop, Thermoscientific) to ensure the presence of DNA to be amplified. The extracted DNA was then amplified by PCR using $16 \mathrm{~S}$ rRNA bacterial primers and several controls were used to ensure the absence of sample contamination by exogenous DNA. The amplification products were assayed using Nanodrop and their quantity was estimated by electrophoresis on $1 \%$ agarose. The amplification products were then separated by Denaturing Gradient Gel Electrophoresis (DGGE) (at 150 volt for 15 minutes then at 20 Volt for $6 \mathrm{~h}$ ) on acrylamide gel with a denaturing gradient (urea, 30-60\% formamide). After migration, the gel was placed for $15 \mathrm{~min}$ in a bath of ethidium bromid and then rinsed for $10 \mathrm{~min}$ with milliQ water. The DNA bands were then visualized under ultraviolet with the gel Geldoc reader 2000 (Bio-Rad, Marnes la Coquette, France) and analysed by Quantity One (Bio-Rad, Marnes la Coquette, France).

\subsection{Metals in Solution and in Sediments}

Sediments were dried at room temperature and sieved with retaining the sediment size fraction of $<250 \mu \mathrm{m}$. Total metals in sediments were quantified before incubation by microwave mineralization according to the method of Bettinelli et al. [29]. Briefly, it consisted in a mineralization with a mix of $6 \mathrm{ml}$ of $\mathrm{HCl}(30 \%), 3 \mathrm{ml} \mathrm{HNO} 3(65 \%)$ and 2 $\mathrm{ml} \mathrm{HF}(40 \%)$ for $250 \mathrm{mg}$ of dry sediment samples. Total metals were analyzed in the river water and of the growing medium after filtration $(0.45 \mu \mathrm{m}$ acid washed membrane filter). The sequential extraction technique proposed by Campanella et al. [30] was followed for partitioning the trace metals and was slightly modified to separate organic matter bound metals and sulphide bound metals. The step allowing to separate organic matter, exchanging for acid-base effect to humic compounds was removed since we are only interested in the metals linked to the totality of organic matter. The different steps of the sequential extraction were the following:

Exchangeable and Carbonate fraction $\left(F_{1}\right): 90 \mathrm{ml}$ of ammonium acetate $(1 \mathrm{M})$ adjusted to $\mathrm{pH} 5$ with acetic acid were added to $9 \mathrm{~g}$ of moist sediments. After shaking at 130 $\mathrm{rpm}$ for $24 \mathrm{~h}$, the mixture was centrifuged at $2400 \mathrm{~g}$ for 15 min. The $\mathrm{pH}$ value was checked at the end of the extraction 
step and the supernatant was recovered.

$\mathrm{Fe}$ and $\mathrm{Mn}$ oxides fraction $\left(F_{2}\right): 90 \mathrm{ml}$ of hydroxyl ammonium chloride (1M)/ acetic acid (25\%) 1:1 (v:v) were added to the sediment residue. The $\mathrm{pH}$ was 3.2 . Then the treatment was the same as the previous step.

Organic matter fraction $\left(F_{3}\right): 50 \mathrm{ml}$ of $\mathrm{NaOH}(0.5 \mathrm{M})$ were added to the sediment residue and the treatment was the same as the previous step.

Sulphide fraction $\left(F_{4}\right): 50 \mathrm{ml}$ of HNO3 $(8 \mathrm{M})$ were added to the sediment residue and the treatment was the same as the previous step. Results obtained in this step must be interpreted very carefully because the residual fraction starts to be attacked.

All recovered supernatants were acidified at $\mathrm{pH} 1$ with nitric acid $(65 \%)$ and kept at $4{ }^{\circ} \mathrm{C}$ before analysis. Metals in solution were subsequently determined by flame atomic absorption spectrometry (Ray Leigh Model WFX-210 AAS) using air-acetylene flame. 7 major elements were analyzed: $\mathrm{Cu}, \mathrm{Cd}, \mathrm{Zn}, \mathrm{Pb}, \mathrm{Fe}, \mathrm{Cr}$ and $\mathrm{Mn}$. Quantification of metals were based upon calibration curves of standard solutions of respective metals. The precision of the metal analysis was controlled by including triplicate samples in analytical batches. The relative standard deviation of mean of triplicate measurements was less than 5\%. Other parameters measured in sediments were $\mathrm{pH}$ of sediment (in situ) and total organic carbon by loss on ignition method after [23, 24, 31].

\section{Results and Discussion}

\subsection{Characterization of Sediments}

The sediments taken have a rather coarse texture. The $\mathrm{pH}$ of the river sediments was about 8.25 indicating slightly the alkaline nature of the sediments. The organic content of the sediment was about $10.80 \%$ which may be due to direct discharge of large amount of industrial and municipal solid wastes released all along the river.

Table 1. Total content of heavy metals in dry sediments $\left(\mu g \cdot g^{-1}\right)$ and river water $\left(\mu g . l^{-1}\right)$ before incubation

\begin{tabular}{llllllll}
\hline Samples & $\mathrm{Pb}$ & $\mathrm{Cu}$ & $\mathrm{Zn}$ & $\mathrm{Cd}$ & $\mathrm{Fe}$ & $\mathrm{Mn}$ & $\mathrm{Cr}$ \\
\hline Sediments & 76.7 & 21 & 32.4 & 37.9 & 19770 & 59 & 53.9 \\
Water & 45.4 & 10.1 & 15.4 & 20.0 & 15501 & 21.5 & 31.1 \\
\hline
\end{tabular}

\subsubsection{Total Metal Contents}

Heavy metal contents in the river water and the sediments collected from the site were analyzed before incubation according to the Bettinelli et al. [29]. Table 1 represents the variation of the total metal contents in sediments and in water. The results for the total metal in sediment ( $\mu$ g.g-1) are the sum of the metal content in the five sediment chemical fractions. A high correlation was exhibited between the total metal concentration in sediments and water for $\mathrm{Zn}, \mathrm{Mn}, \mathrm{Pb}$, $\mathrm{Cu}, \mathrm{Cd}, \mathrm{Cr}$ and $\mathrm{Fe}$. These correlations suggest that some kind of water-sediment interaction is taking place. In the dry season, when the river discharge is very low, an interaction or reaction occurs between bed load sediments and water, thus an equilibrium between the bed load and water may be achieved $[32,33,34]$ and what should be noted is that the discharge of the river is very low and therefore, it would be plausible to assume that the metal pollutants enter the river where the conditions approximately are that of the closed system and then interact with sediment. They partition within the available sediment chemical fractions, interact with the existing water complexes and differentiate into different chemical species. This correlation of metals in sediment and water suggests that their contents in sediments are mainly due to human activities $(\mathrm{Cr}, \mathrm{Cd}, \mathrm{Zn}, \mathrm{Mn}, \mathrm{Pb}$ and $\mathrm{Cu})[35,36]$. Total heavy metal concentrations in the water and the bed sediments decreases in the order of $\mathrm{Fe} \square$ $\mathrm{Pb} \square \mathrm{Mn} \square \mathrm{Cr}>\mathrm{Zn} \square \mathrm{Cd} \square \mathrm{Cu}$.

\subsubsection{Sequential Extraction}

It was performed on the sediments of the studied site before incubation. Table 2 lists the metal contents in the different fractions of the sediment before incubation. Results showed that the different metals are differently distributed in the different chemical fractions. The difference between the Fe sediment speciation and the other metals $(\mathrm{Cd}, \mathrm{Pb}, \mathrm{Zn}, \mathrm{Cr}, \mathrm{Cu}$ and $\mathrm{Mn})$ can be attributed to the source of the $\mathrm{Fe}$ in sediments and its geochemistry. Metals of natural origin occur primarily in the residual sediment fraction [37, 38, 39]. Iron which is abundant in the sediments occurred primarily in F5, the resistant residual chemical fraction (Table 2). This is consistent with a natural source for $\mathrm{Fe}$ in the river sediments. The chemistry of $\mathrm{Fe}$ can explain the speciation of $\mathrm{Fe}$ in the $\mathrm{Fe} / \mathrm{Mn}$ oxides fraction and its nil speciation in the exchangeable/carbonate fraction [40, 41]. $\mathrm{Cu}$ showed its highest concentration (Table 2) in the organic matter fraction (F3) and the sulphide fraction (F4). Cr showed its highest concentration in the Fe-Mn oxides fraction (F2), organic matter fraction (F3) and sulphide fraction (F4).

Table 2 Contents of metals in the different fractions of the sediment before incubation ( $F_{1}$ Exchangeable/Carbonate ; $F_{2} F e / M n$ oxides; $F_{3}$ organic; $F_{4}$ sulphide; $F_{5}$ Residual).

\begin{tabular}{llllllll}
\hline Content $\left(\mu \mathrm{g} . \mathrm{g}^{-1}\right)$ & $\mathrm{Pb}$ & $\mathrm{Cu}$ & $\mathrm{Zn}$ & $\mathrm{Cd}$ & $\mathrm{Fe}$ & $\mathrm{Mn}$ & $\mathrm{Cr}$ \\
\hline $\mathrm{F}_{1}$ & 20.3 & 3.42 & 7.78 & 14.2 & 786 & 15.3 & 2.3 \\
$\mathrm{~F}_{2}$ & 25.4 & 1.35 & 5.84 & 13.2 & 7320 & 15.7 & 20.1 \\
$\mathrm{~F}_{3}$ & 18.2 & 6.2 & 2.44 & 7.5 & 586 & 4.2 & 15.1 \\
$\mathrm{~F}_{4}$ & 5.36 & 9.57 & 15.3 & 1.6 & 3545 & 2.4 & 12.1 \\
$\mathrm{~F}_{5}$ & 7.4 & 0.55 & 1 & 1.4 & 7531 & 21.45 & 4.2 \\
Total Contents & 76.7 & 21.1 & 32.4 & 37.9 & 19770 & 59.1 & 53.9 \\
\hline
\end{tabular}

Mn showed its highest concentration in the residual Fe-Mn oxides fraction and exchangeable/Carbonate fraction (F1). The speciation pattern of $\mathrm{Zn}$ showed that it belonged mainly to the sulphide fraction (F4). $\mathrm{Cd}$ and $\mathrm{Pb}$ belonged mainly to the carbonate fraction and $\mathrm{Fe} / \mathrm{Mn}$ oxides fraction. However, $\mathrm{Cd}$ and $\mathrm{Pb}$ exhibited strong correlation on their 
metal speciation patterns in the sediments (Table 2). The highest concentrations of $\mathrm{Pb}$ and $\mathrm{Cd}$ metal contents are in the exchangeable/carbonate fraction (F1) and the Fe/Mn-oxides fraction (F2). However, $\mathrm{Cd}$ had a higher association than $\mathrm{Pb}$ with the exchangeable/carbonate fraction (F1) and a lower association with the Fe/Mn oxides one (F2) (Table 2). The higher association of $\mathrm{Pb}$ in the moderately reducible fraction is due to the higher stability constant of $\mathrm{Pb}$-oxides than Cd-oxides [42].

\subsection{Evolution of the Microbial Metabolism, Density and Diversity}

\subsubsection{Evolution of the Microbial Metabolism}

The rate of carbon mineralization of the sediment samples was high from the beginning of the experiment till the fifth day of incubation before the stationnary phase was observed (Fig.2). No log period was observed meaning a good physiological state of microorganisms and a good adaptation to the experimental conditions. Glucose was degraded after 5 days of incubation with the production of large quantities of organic and inorganic carbon and several organic acids: acetate, lactate, butyrate and succinate. Butyrate and acetate appeared to be the major organic acids produced by the bacteria after 5 days of incubation with a maximum value attained of 8.296 and $3.673 \mathrm{mg}$ of carbon, respectively. Only small amounts of lactate and succinate were produced $(0.665$ and $0.286 \mathrm{mg}$ of carbon, respectively). The production of such organic acids indicated the occurrence of the fermentation process [20]. Furthermore, Dassonville et al. [43] demonstrated that soils enriched with glucose under anaerobic conditions, the microbial metabolism of glucose led to the initial formation of $\mathrm{CO} 2$ and acetate, while smaller quantities of lactate were accumulated [44]. About 50\% of the organic carbon introduced as glucose was transformed into organic acids and mineralized carbon after 5 days of incubation. The organic carbon not determined can be due to the production of other metabolites such as alcohols, amino-acids and polysaccharides not analysed and to the increase of the biomass of the iron-reducing bacteria and Clostridium perfringes.
Indeed microorganisms increased from about $2.7 \times 105$ to $6.2 \times 105$ CFU.g-1 of dry sediments for the iron-reducing bacteria and from about $7 \times 104$ to $2.3 \times 105$ CFU.g- 1 of dry sediments for Clostridium perfringes after 5 days of incubation and which was the maximum and therefore the organic acid production patterns in our incubations indicated that microorganisms had a fermentative metabolism rather than an anaerobic respiration since glucose was mainly transformed into carbon dioxide and organic acids.

The production of such molecules during the incubation period was responsible for the acidification of the medium where it was shown that the $\mathrm{pH}$ decreases from 8.2 and arrives to 5.4 at the end of the incubation.

The modification of the metabolic activity during incubation can be either due to a modification of the microbial population or due to a modification of the metabolic pathways of the same communities. To detect which of these processes have been taken place during incubation, it was necessary to study the evolution of the microbial density and diversity.

\subsubsection{Evolution of the Microbial Density}

A high variability in the concentrations of the different types of the detected bacteria was observed before and during incubation (Fig.3) where it was shown that the density of the iron-reducing bacteria and Clostridium perfringes has increased dramatically from $2.7 \times 105$ CFU.g-1 and $7 \times 104$ CFU.g- 1 and reached a pic after 5 days of incubation with $6.2 \times 105$ CFU.g-1 and $2.3 \times 105$ CFU.g-1 of dry sediments, respectively. The pics observed during this incubation period showed that these bacterial communities have been rapidly adapted to the culture conditions and their growth have been accelerated due to the presence of glucose as a source of carbon which is easily accessible and degradable.

After this period, the density has decreased to stabilize around 5.6×105 and $2 \times 105$ CFU.g- 1 of dry sediments at the end of the incubation for iron-reducing bacteria and Clostridium perfringes, respectively.

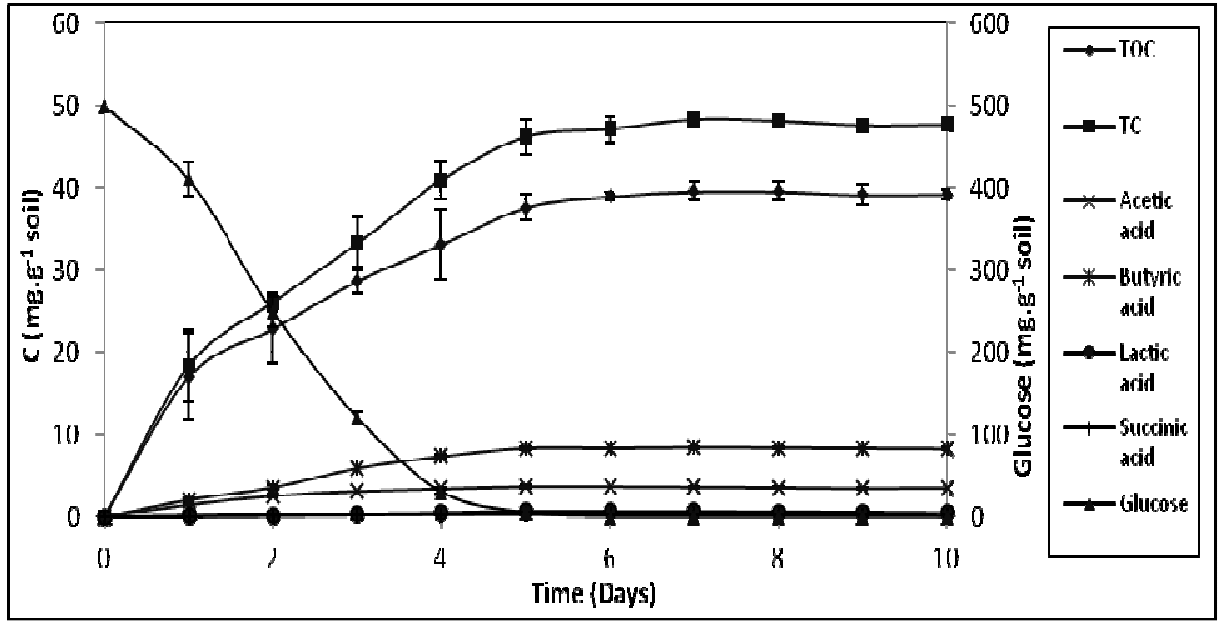

Figure 2. Evolution between organic and inorganic carbon during incubation 

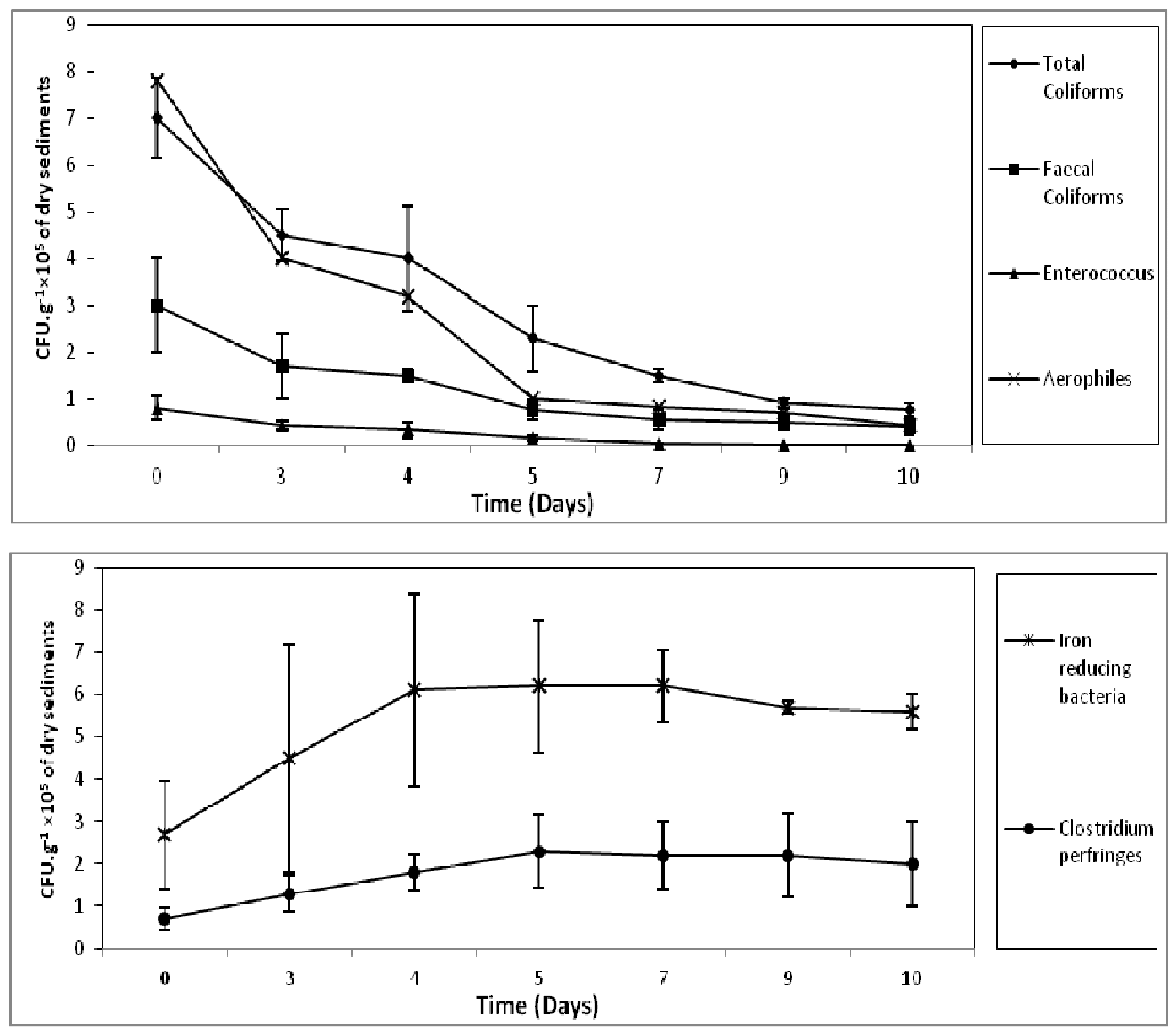

Figure 3. Evolution of the microbial density during incubation of the sediments

At the same time, persistence of TC, FC and aerophilic bacteria in the experiment decreased with time during the experiment. Zhai et al. [45] reported a substantial reduction (greater than 99\%) of faecal coliform and faecal streptococci concentrations after 2 weeks in an incubation experiment with poultry manure. Here, it was shown that the density of TC, FC, enterococcus and aerophilic bacteria begin to decrease from the 3rd and 4rth days to reach around $7.6 \times 104,4 \times 104,3 \times 102$ and $4.3 \times 104$ CFU.g- 1 of dry sediments, respectively at the end of the incubation period. The survival of these bacteria in the incubated sediments depends on many parameters such as the $\mathrm{pH}$ of the media, the aerated conditions, the media composition $[46,47,48]$ and the presence of other microorganisms and a change in these conditions was shown to be unfavorable for their survival but also suitable for the development of iron-reducing bacteria where it was shown that the density of these later increased and the density of coliforms, aerophiles and enterococcus decreased at the same time of the production of organic acids and the acidification of the media $[49,50]$.

\subsubsection{Evolution of the Microbial Diversity}

The DNA bands observed in DGGE were compared before and during incubation. Each band was numbered (Fig.4). For the sediments, a significant change was observed before and after 5 days of incubation which confirms that the change in the metabolic activity is mostly due to a change in the bacterial communities. Many DNA bands appear or worsen. These bands may therefore correspond to the development of many species of the fermentative type which were present in small concentrations and have been developed following the addition of glucose.

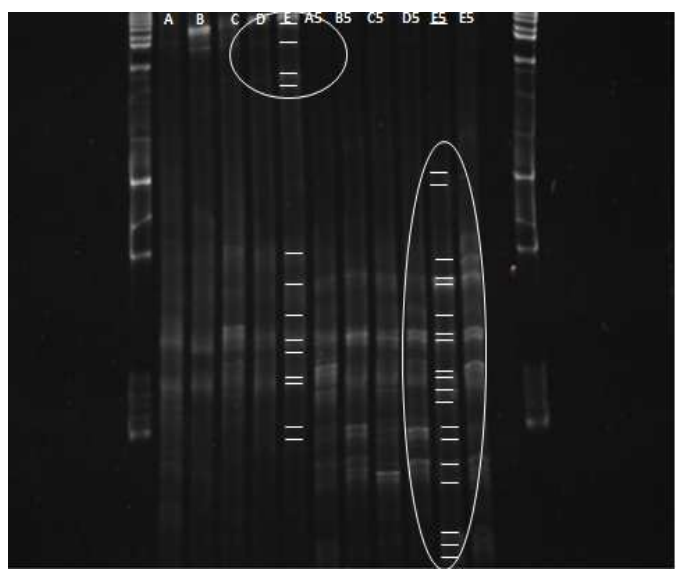

Figure 4. Evolution of DGGE profiles before and during incubation of sediments from the site $E$ (Note: Point $E$ represents the sediments of the site $E$ before their incubations and the point E5 represent the same sediments after 5 days of incubation). 


\subsection{Metals in Solution and Sediments and Their Relationship with the Microbial Metabolism}

Fig 5. showed that the rate of the dissolution of iron and manganese was similar in the incubated sediments. This solubilisation rate was shown to be high during the first five days of incubation and was followed by a plateau. Maximum contents of $\mathrm{Fe}$ and $\mathrm{Mn}$ were 2220 and 19.3 mg.ml-1, respectively. The dissolution of $\mathrm{Fe}$ and $\mathrm{Mn}$ was maximum during the first days of the experiments and synchronous with the high decrease of $\mathrm{pH}$. Several processes may be involved in the general positive relationship between lowering of $\mathrm{pH}$ and metal release, which has been widely demonstrated for various substrates $[6,7,8,9,51,52,53,54]$. What was important was the high correlation found between carbon mineralization and the release of Fe (Fig.2 and Fig.5), where it can be noticed that dissolved iron attained a plateau when glucose was completely consumed and when organic acids are produced especially acetate and butyrate which is a characteristic feature of the microorganism Clostridium butyricum which is known for its iron reducing activity [18] and therefore indicating the presence and the effect of iron reducing bacteria.

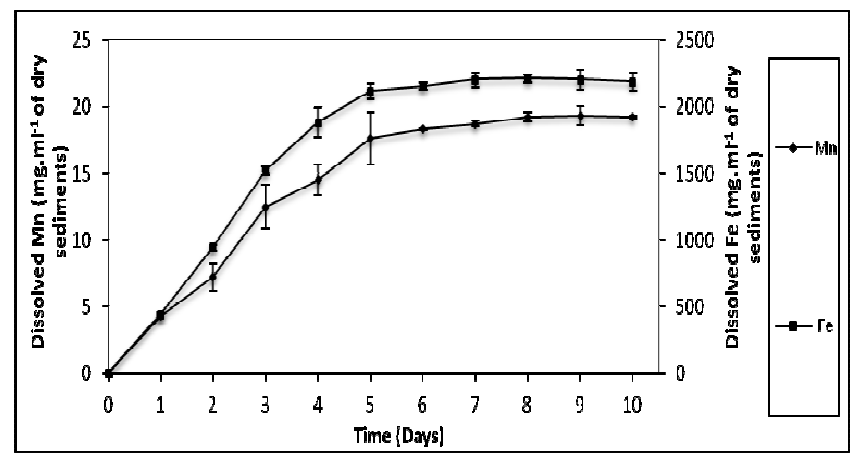

Fig 5. Evolution of the contents of dissolved Fe and Mn during their incubation

For $\mathrm{Pb}, \mathrm{Cu}$ and $\mathrm{Zn}$, maximum dissolution contents were $3.20 ; 0.38 ; 1.47 \mathrm{mg} . \mathrm{ml}-1$, respectively (Fig. 6). The dissolved contents of the other metals were very low during the incubation (such for $\mathrm{Cd}$ and $\mathrm{Cr}$ ). High correlations were found between the dissolution profiles of $\mathrm{Fe}$ and $\mathrm{Pb}, \mathrm{Mn}$ and $\mathrm{Zn}$ in the sediments suggesting that the reductive dissolution of Fe-oxides in the sediments is highly correlated with the mobilization of the heavy metals and that these metals have been released from iron oxides and this correlation was detected from the beginning of the experiment.

Fig.7 showed that the mobilization of Fe-oxide and the heavy metals $(\mathrm{Mn}, \mathrm{Cu}, \mathrm{Zn}$ and $\mathrm{Pb}$ ) was divided into 2 parts and this can be explained by the presence of 2 types of iron oxides (amorphous and crystallized) [55]. Initially, the amorphous Fe-oxide agglomerates (ferrihydrite) were easily accessible to bacteria, which justifies the strong $\mathrm{Fe}$ dissolution rate at the beginning of the incubation and at a rate higher than that of the other metals. Later, the bacteria could not access to the tiny pores of the ferrihydrite agglomerate structure $[56,57]$ which resulted in a decrease of the Fe dissolution rate and a higher dissolution rate of the studied metals.

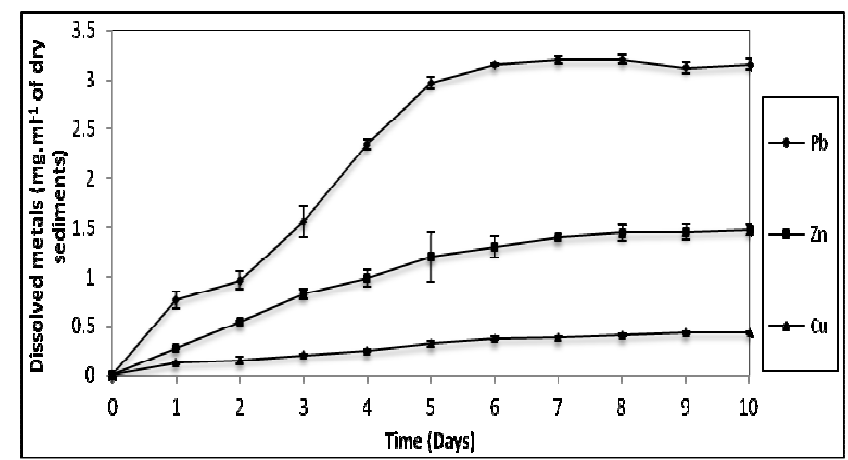

Figure 6. Evolution of the content of dissolved $\mathrm{Pb}, \mathrm{Cu}$ and $\mathrm{Zn}$ during their incubation

By contrast, the dissolution of the crystallized iron oxide (hematite, goethite) did not stop and was delayed as compared to that of ferrihydrite which explain the later increase in the dissolution of heavy metals. An important part of these trace elements could be eliminated from the sediments and the soil solution to get into the hydrosystem when the water level decreases. Iron oxides reduction has also been suggested as a mechanism for heavy metal mobilization into underground waters $[58,59,60]$.
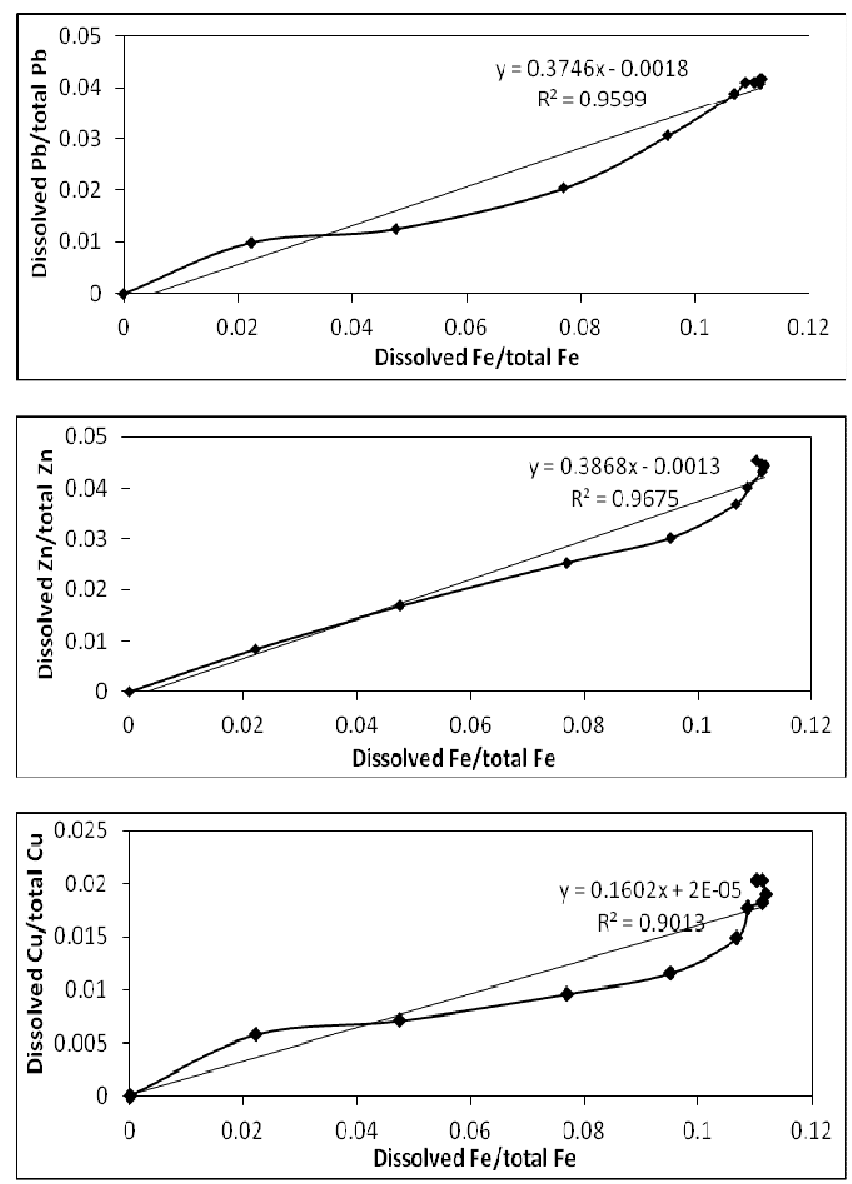


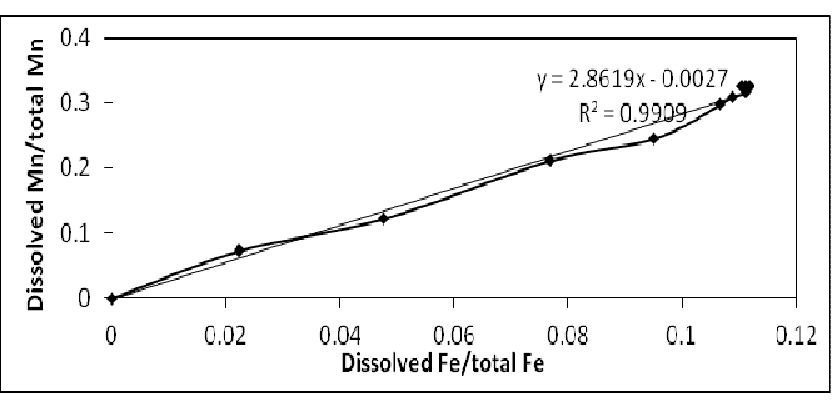

Figure 7. Correlation between dissolved metals and dissolved Fe for the dissolved metals during incubation

\section{Conclusion}

During incubation, the organic matter was fermented and $\mathrm{CO} 2$ and organic acids were produced and the release of $\mathrm{Cu}$, $\mathrm{Pb}, \mathrm{Zn} \mathrm{Fe}$, and $\mathrm{Mn}$ occurred. A strong correlation was noticed between the dissolution of $\mathrm{Fe}$ and the other metals. This fact led to think that $\mathrm{Pb}, \mathrm{Zn}$ and $\mathrm{Mn}$ were leached from iron-oxides by iron-reducing bacteria. Furthermore, the presence of iron-reducing bacteria was highlighted by the analysis of organic acids and particularly a high concentration of butyrate, which is usually produced by the iron-reducing bacterium, Clostridium butyricum. Finally, the microbiological analysis of the sediments before and during incubation showed a modification of the bacterial population after 5 days of incubation where the density of many bacterial populations has decreased due to the toxicity of the released heavy metals while others intensified because they were tolerant to the same conditions and this was clearly detected by the genetic analysis of the bacterial diversity done on the same samples which showed the changes of the bacterial communities after their incubation which have been detected by the intensification of the DNA bands corresponding to the development of bacteria of the fermentative type and the disappearance of many bands corresponding to the disappearance or decrease of many bacterial populations.

In the context of these experiments, the recreated conditions were different from the field conditions where the soil containing the contaminants is traversed by fluid and the contact time is much shorter where certain observed reactions in the closed reactors didn't have the time to be initiated. Therefore, it would be interesting in further studies to compare the results obtained in closed reactors to those obtained in laboratory column experiments and under the conditions of dynamic transfer to obtain a model of mobilization of metals on soil and it is also necessary to identify the effect of the detected microorganisms, through their interaction with the different components of the soil, on the mobility of heavy metals through the process of transport (convection/dispersion) and other heterogeneous phenomena (dissolution/precipitation, oxydoreduction, adsorption/ desorption) and the drainage of these metals and different microorganisms to the underground water.

\section{Acknowledgments}

The authors like to express their thanks to laboratory assistant Vanessa ALPHONSE at the laboratory BIOEMCO and to the Ecole Doctorale for Sciences and Technology (EDST) and especially to the laboratory assistant Manal HOUHOU for realizing the AAS measurements and to Samira ZAHER at Afif Beydoun Laboratory at the Faculty of Sciences I-Hadath for realizing the HPLC and TOC analysis.

\section{References}

[1] A. Tessier and H. Hare, "Predicting animal cadmium concentrations in lakes", Nature 380, 1996, pp. 430-432.

[2] M. Klavins, A. Briede, V. Rodi, I. Kokorite, E. Parele and I. Klavinš, "Heavy metals in rivers of Latvia", Sci. Total Environ. 262, 2000, 175-183.

[3] S.N. Luoma, "Bioavailability of trace metals to aquatic organism- a review", Sci. Total Environ. 28, 1983, pp.1-22.

[4] A.S. Jumbe, and N. Nandini, "Heavy metals analysis and sediment quality values in Urban Lakes", American Journal of Environmental Sciences, vol 5(6), 2009, pp. 678-687.

[5] V. Cappuyns, R. Swennen, and A. Devivier, "Dredged River Sediments: Potential Chemical Time Bombs ? a Case Study", Water, Air, \& Soil Pollution, 171, 2006, pp.49-66.

[6] W. Calmano, J. Hong, and U. Förstner, "Binding and mobilization of heavy metals in contaminated sediments affected by $\mathrm{pH}$ and redox potential", Water Science and Technology, 28, 1993.

[7] S.Y. Chen, and J.G. Lin, "Bioleaching of heavy metals from sediments: significance of pH", Chemosphere, 44, 2001, pp.1093-1102.

[8] M.C. Chuan, G.Y. Shu, and J.C. Liu, "Solubility of heavy metals in a contaminated soil: Effects of redox potential and pH”, Water, Air, and Soil Pollution, 90, 1996, pp. 543-556.

[9] J.L. Sims, and W.H. Patrick, "The distribution of micronutrient cations in soil under conditions of varying redox potential and $\mathrm{pH}$ ", Soil Science Society of America Journal, 42, 1978, pp. 258-262.

[10] J.M. Zachara, J.K. Fredrickson, S.C. Smith, et P.L. Gassman, "Solubilization of $\mathrm{Fe}(\mathrm{III})$ oxide-bound trace metals by a dissimilatory $\mathrm{Fe}(\mathrm{III})$ reducing bacterium", Geochimica et Cosmochimica Acta; 65, 2001, pp. 75-93.

[11] K. Bosecker, "Bioleching: metal solubilization by microorganisms", FEMS Microbiology Reviews; 20, 1997, pp. 591-604.

[12] M. Ledin, "Accumulation of microorganisms-processes and importance for soil systems", Earth-Science Reviews, 51: 2000, pp.1-31.

[13] P.M. Huang, M.K. Wang, and C.Y. Chiu, "Soil mineral-organic matter-microbe interactions: Impacts on biogeochemical processes and biodiversity in soils", Pedobiologia, 49, 2005, pp. 609-635. 
[14] G.M. Gadd, "Microbial influence on metal mobility and application for bioremediation", Geoderma, 122, 2004, pp. 109-119.

[15] C. Gomez, and K. Bosecker, "Leaching Heavy Metals from Contaminated Soil by Using Thiobacillus ferrooxidans or Thiobacillus thiooxidans", Geomicrobiology Journal, 16: 1999, pp. 233-244.

[16] A.T. Lombardi, J. Garcia, and Oswaldo, "Biological leaching of $\mathrm{Mn}, \mathrm{Al}, \mathrm{Zn}, \mathrm{Cu}$ and $\mathrm{Ti}$ in an anaerobic sewage sludge effectuated by Thiobacillus ferrooxidans and its effect on metal partitioning", Water Research, 36, 2002, pp. 3193-3202.

[17] H.W. Ryu, H.S. Moon, E.Y. LEE, K.S. CHO, and H. CHOI, "Leaching characteristics of heavy metals from sewage sludge by Acidithiobacillus thiooxidans MET", Journal of Environmental Quality, 32, 2003, pp. 751-759.

[18] D.R. Lovley, "Dissimilatory Fe (III) and Mn (IV) reduction". Microbiological reviews, 55, 1991, pp. 259-287.

[19] O. Regnel, and A. Tunlid, "Laboratory study of chemical speciation of mercury in lake sediment and water under aerobic and anaerobic conditions". Applied and Environmental Microbiology; 57, 1991, pp. 789-795.

[20] R. Charlatchka, and P. Cambier, "Influence of Reducing Conditions on Solubilty of Trace Metals in Contaminated Soils", Water, Air, \& Soil Pollution, 118, 2000, pp. 143-168.

[21] S. Carpentier, R. Moilleron, C. Beltran, D. Herve, and D. Thevenot, "Quality of dredged material in the River Seine basin (France) I. Physico-chemical properties", The Science of The Total Environment, 295, 2002a, pp. 101-113.

[22] S. Carpentier, R. Moilleron, C. Beltran, D. Herve, and D. Thevenot, "Quality of dredged material in the river Seine basin (France). II. Micropollutants". The Science of The Total Environment, 299, 2002b, pp. 57-72.

[23] H. Sakai, Y. Kojima, and K. Saito, "Distribution of metals in water and sieved sediments in the Toyohira river", Water Research , 20, 1986, pp. 559-567.

[24] V. Subramanian, R.V. Grieken \& D.L. Vant, "Heavy metal distribution in the sediments of Ganges and Brahmaputra rivers", Environmental Geology and Water Sciences, 9(2), 1987, pp. 93-103.

[25] N. Bousserrhine, U.G. Gasser, E. Jeanroy, and J. Berthelin, "Comparison between bacterial and chemical dissolution of Al-substituted goethite". Incidence on mobilization of iron. Effect of mineral-organic-microorganism interactions on soil and freshwater environments. Berthelin J, Huang PM, Bollag J-M et Andreux F, Kluwer Academic/Plenum Publishers: 1999a, pp. 378.

[26] N. Bousserrhine, U.G. Gasser, E. Jeanroy, and J. Berthelin, "Bacterial and chemical reductive dissolution of Mn-, Co-, Cr-, and Al- substituted goethites", Geomicrobiology Journal, 16 (3), 1999b, pp. 245-258.

[27] M.A. Tormo, and J.M. Izco, "Alternative reversed-phase high-performance liquid chromatography method to analyse organic acids in dairy products", Journal of Chromatography A, 1033(2), 2004, pp. 305-310.

[28] N., Bousserrhine, "Etude de paramètres de la réduction bactérienne du fer et application à la defferification de minéraux industriels", Université Henry Poincaré, Nancy I; 1995, pp. 331.

[29] M. Bettinelli, G.M. Beone, S. Spezia, and C. Baffi, "Determiantion of heavy metals in soils and sediments by microwave-assisted digestion and inductively coupled plasma optical emission spectrometry analysis", Analytica Chimica Acta; 424, 2000, pp.289-296.

[30] L. Campanella, D. D’Orazio, B.M. Petronio, and E. Pietrantonio, "Proposal for a metal speciation study in sediments", Analytica Chimica Acta, 309, 1995, pp. 387-393.

[31] APHA: Standard Methods for the Examination of Water and Wastewater, $20^{\text {th }}$ ed., American Public Health Association, Washington, DC. 1998.

[32] A. Tesorierio, J.F. Pankow, "Solid-solution partitioning of $\mathrm{Sr}^{2+}, \mathrm{Ba}^{2+}$ and $\mathrm{Cd}^{2+}$ to calcite", Gechim. Cosmochim. Acta 60, 1996, pp.1053-1063.

[33] M. Piron, A. Pineau, and R.M. Mabele, "Sediment parameters and distribution of metals in fine sediments of the Loire esturary”, Water, Air, Soil Poll. 50, 1990, pp. 267-277.

[34] Fw. Ntengwe, "Pollutant loads and water quality in stream of heavily popualted and industrialized towns", Phys Chem Earth 31, 2006, pp. 832-839.

[35] S.I. Korfali, "Metal Concentrations in The Nahr-Ibrahim River", Lebanon, Ph.D. Thesis, University of Bradford, UK. 1999.

[36] S.I. Korfali, and B.E. Davies, "Total and extractable trace elements in Lebanese river sediments: dry season data", Environ. Geochem. Health 22, 2000, pp. 265-273.

[37] B. Jones, and A. Turki, "Distribution and speciation of heavy metals on surficial sediments from the Teas Estuary, North-east England", Mar. Pollut. Bull. 34, 1997, pp. 768-779.

[38] L. L'Her Roux, S. La Roux, and P. Appriou, "Behavior and speciation of metallic species $\mathrm{Cu}, \mathrm{Cd}, \mathrm{Mn}$, and $\mathrm{Fe}$ during estuarine mixing”, Mar. Poll. Bull.36, 1998, pp. 56-64.

[39] C. Ianni, E. Magi, P. Rivaro \& N. Ruggieri, "Trace metals in Adriatic coastal sediments: distribution and speciation pattern”, Toxicol. Environ. Chem. 78, 2000, pp. 73-92.

[40] S.P. Singh, F.M. Tack, and M.G. Verloo, "Heavy metal fractionation and extractability in dredged sediment derived surface soils". Water, Air, and Soil Pollution, 102, 1998, pp. 313-328.

[41] K. Selvaraj, V. Mohan Ram, S. Piotr, "Evaluation of Metal Contamination in Coastal Sediments in Bay of Bengal. India: Geochemical and Statistical Approaches", Marine Pollution Bulletin, 49, 2004, pp. 174-185.

[42] L. Ramos, L.M. Hernandez, and M.J. Gonzalez, "Sequential fractionation of copper, Lead, cadmium and zinc in soils from near Donana National Park", J. Environ. Qual. 23, 1990, pp. 50-57.

[43] F. Dassonville, J.J. Godon, P. Renault, A. Richaume, and P. Cambier, "Microbial dynamics in an anaerobic soil slurry amended with glucose, and their dependence on geochemical processes", Soil Biology and Biochemistry, 36: 2004, $1417-1430$ 
[44] D.R. Lovley, and E.JP Phillips, "Novel mode of microbial energy metabolism: organic carbon oxidation coupled to dissimilatory reduction of iron or manganese". Applied and Environmental Microbiology, 54, 1988, pp.1472-1480.

[45] Q. Zhai, M.S. Coyne, R.I. Barnhiel, "Mortality rates of faecal bacteria in subsoil amended with poultry manure", Bioresour. Technol. 54, 1995, pp.165- 169.

[46] C.M. Davies, J.A.H. Long, M. Donald, and N.J. Ashbolt, "Survival of fecal microorganisms in marine and freshwater sediments". Applied and Environmental Microbiology, 61(5): 1995, pp. 1888-1896.

[47] Y. J. An, D. H. Kampbell, and G.P. Breidenbach, "Escherichia coli and total coliforms in water and sediments at lake marinas". Environmental Pollution, 120, 2002, pp.771-778.

[48] G. J. Medema, S. Shaw, M. Waite, M. Snozzi, A. Morreau, W. Grabow, "Catchment characterization and source water quality". In: Assessing Microbial Safety of Drinking Water: Improving Approaches and Methods (A. Dufour, M.Snozzi, W. Koster et al., eds.). WHO OECD, London, 2003, 111-158.

[49] T.P. Curtis, D.D. Mara, S. A. Silva, "Influence of $\mathrm{pH}$, oxygen, and humic substances on ability of sunlight to damage fecal coliforms in waste stabilization pond water", Applied and Environmental Microbiology, 58(4), 1992, 1335-1343.

[50] P. Van der Steen, A. Brenner, Y. Shabtai, G. Oron, "Improved fecal coliform decay in integrated duckweed and algal ponds". Water Science and Technology, 42(10-11), 2000, pp.363-370.

[51] W. Stumm, J.J. Morgan, "Aquatic chemistry, chemical equilibria and rates in natural waters", Trace Metals: Cycling, Regulation, and Biological Role. 3rd ed. John Wiley and Sons, Inc, USA, 1996.

[52] P. Gunder, and E. Steinnes, "Influence of $\mathrm{pH}$ and TOC concentration on $\mathrm{Cu}, \mathrm{Zn}, \mathrm{Cd}$ and $\mathrm{Al}$ speciation in rivers", Water Research, 37, 2003, pp. 307-318.
[53] S. Qureshi, B.K. Richards, A.G. Hay, C.C. Tsai, M.B. Mcbride, P. Baveye, and T.S. Steenhuis, "Effect of microbial activity on trace element release from sewage sludge", Environmental Science \& Technology; 37, 2003, pp. 3361-3366.

[54] J.Y. Yang, X.E. Yang, Z.L. He, T.Q. Li, J.L. Shentu, and P.J. Stoffela, "Effects of $\mathrm{pH}$, organic acids, and inorganic ions on lead dissolution from soils", Environmental Pollution, 143, 2006, pp.9-15.

[55] M. Fakih, M. Davranche, A. Dia, B. Nowack, P. Petitjean, X. Châtellier, and G. Gruau, "A new tool for in-situ minitoring of Fe-mobilization in soils", Appl. Geochem. 23, 2008, pp. $3372-3383$.

[56] E.E. Roden, and J.M. Zachara, "Microbial reduction of crystalline iron (III) oxides: influence of oxide surface area and potential for cell growth", Environ, Sci, Technol. 30, 1996, pp. 1618-1628.

[57] E.E. Roden, "Fe (III) oxide reactivity toward biological versus chemical reduction", Environ. Sci. Technol. 37 (7), 2003, pp.1319-1324.

[58] R.T. Nickson, J.M. Mcarthur, P. Ravenscroft, W.G. Burgess, and K.M. Ahmed, "Mechanism of arsenic release to groundwater, Bangladesh and West Bengal", Appl. Geochem. 15, 2000, pp. 403-413.

[59] P. Bose, and A. Sharma, "Role of iron in controlling speciation and mobilization of arsenic in subsurface environment”. Water Res. 36(19), 2002, pp.4916-4926.

[60] A. Van Geen, J. Rose, S. Thoral, J.M. Garnier, Y. Zheng, and J.Y. Bottero, "Decoupling of As and Fe release to Bangladesh groundwater under reducing conditions", Part II. Evidence from sediment incubations. Geochim. Cosmochim. Acta 68: 2004, pp. 3475-3486. 